\title{
Assessment of the immune and antitumor effects of products from Sea hare inhabiting the Egyptian water using an experimental tumor mouse model
}

Mai Ziada, Mohamed Mona, Mohamed Basyony and Mohamed L. Salem

Zoology Department, Faculty of Science, Tanta University, Tanta, Egypt

\section{III}

Background: Although anticancer chemotherapy is effective, it has side effects. Novel agents with potent anti-tumor effects are needed, potential source could be extracted from marine animals since they possess products with anticancer effect. Aim: the aim of this study was to study the potential anti-tumor effect of egg extract and purple fluid in vitro. EAC cells were incubated with different concentrations of both extracts in vitro for 24 hours and then cell cycle, apoptosis was analyzed by flow cytometry and survival was analyzed by trypan blue exclusion and MTT assays. Incubation of EAC cells with both extracts resulting in significant decreasing in number of cells and increasing in apoptosis in a dose dependent manner. Untreated cells were negative control, cells treated with cisplatin were positive control. Results: Egg extract at $(50 \mu \mathrm{g} / \mathrm{ml}, 100 \mu \mathrm{g} / \mathrm{ml}, 150 \mu \mathrm{g} / \mathrm{ml}, 200 \mu \mathrm{g} / \mathrm{ml}, 250 \mu \mathrm{g} / \mathrm{ml})$ induced $(68 \%, 60 \%, 55 \%, 48 \%, 42 \%)$ respectively in proliferation, and $(6.3 \%, 6.4 \%, 7 \%, 7.1 \%, 7.2 \%)$ increases in apoptosis. Purple fluid at $(0.5 \mu \mathrm{g} / \mathrm{ml}, 1 \mu \mathrm{g} / \mathrm{ml}, 1.5 \mu \mathrm{g} / \mathrm{ml}, 2 \mu \mathrm{g} / \mathrm{ml})$ induced (55\%, 50\%, 45\%, $35 \%)$ respectively in proliferation, and $(5 \%, 7.1 \%, 7.2 \%, 11.5 \%)$ increases in apoptosis. Conclusion: both egg extract and purple fluid showed significant anti-tumor efficacy which, further studies required to evaluate the potential efficacy.

Editor-in-Chief: Prof. M.L. Salem, PhD - Article DOI: 10.21608/JCBR.2021.61856.1170 